\title{
Kesadaran Lingkungan Masyarakat Jakarta Timur dalam Mengantisipasi Bencana Banjir Besar Setiap Tahun se-JABODETABEK
}

\author{
Eka Sartika, Prof. Dr. Amos Neolaka, Dr. Gina Bachtiar, MT
}

\section{PENDAHULUAN}

Menumbuhkan kesadaran masyarakat terhadap upaya pelestarian lingkungan memang perlu dilakukan secara intensif. Pada beberapa kesempatan, kita pasti pernah menyaksikan hal-hal yang membuat miris, terkait perilaku masyarakat yang tidak ramah lingkungan. Ketika dalam perjalanan hendak ke kampus, tiba-tiba dari jendela mobil yang ada di depan saya terlontar kemasan air minum mineral yang mengotori badan jalan. Beberapa hari kemudian kejadiannya agak berbeda, dari jendela sebuah mobil truk terlontar sobekan-sobekan kertas yang melayanglayang dan akhirnya mengotori jalanan. Kejadian lain cukup memalukan juga, dari jendela sebuah mobil yang tergolong mewah dibuang kemasan kue yang berceceran di jalan. Kejadiankejadian ini merupakan contoh perilaku masyarakat yang tidak peduli pada kebersihan lingkungan. Perilaku manusia yang tidak sadar lingkungan inilah yang menjadi salah satu penyebab terjadinya banjir.

Bencana banjir dapat terjadi karena faktor alamiah maupun pengaruh perlakuan masyarakat yang tidak bertanggung jawab terhadap alam dan lingkungannya. terjadinya banjir dan bencana terlihat bahwa faktor alamiah yang utama adalah curah hujan. Faktor alami lainnya adalah erosi dan sedimentasi kapasitas sungai, kapasitas drainase yang tidak memadai, pangaruh air pasang, dll. Sedangkan salah satu faktor non-alamiah penyebab banjir adalah faktor sosiohidraulik yang diartikan sebagai kepahaman sosial tentang masalah yang berkaitan dengan keairan dan konservasinya. Selama masyarakat di kota maupun di desa belum paham tentang keterkaitan antara daerah hulu dan hilir, banjir dan kekeringan, sampah dan banjir, penebangan pohon/hutan dan banjir, serta bagaimana dan dengan cara apa seharusnya mereka berbuat, maka pemahaman terhadap faktor sosio-hidraulik belum tercapai.

Upaya yang dilakukan oleh pemerintah dalam menanggulangi banjir dengan membangun banjir Kanal sudah berdampak bagi sebagian warga di daerah hilir. Warga yang berada di daerah hilir 
sekitar banjir kanal memang sudah tidak terkena banjir lagi, namun bagi warga di daerah hulu masih saja mengalami banjir tahunan. Ternyata upaya yang dilakukan pemerintah DKI Jakarta ini belum sepenuhnya bisa mengatasi masalah banjir di Jakarta. Oleh karena itu bagi warga yang masih terkena banjir harus sebisa mungkin mengantisipasinya. Dalam mengantisipasi banjir perlu adanya sikap kesadaran lingkungan.

Untuk munumbuhkan rasa kesadaran dalam diri perlu dipelajari dan dipahami terlebih dahulu tentang pengertian dari kesadaran itu sendiri. Hasil penelitian teoritik tentang kesadaran lingkungan hidup dari Amos Neolaka (1991:18), menyatakan bahwa kesadaran adalah keadaan tergugahnya jiwa terhadap sesuatu, dalam hal ini terhadap lingkungan hidup, dan dapat terlihat pada perilaku dan tindakan masing-masing individu.

Definisi operasional kesadaran ialah keadaan mengerti apa yang dilakukan dan bertindak dengan aktif pada kondisi sadar. Definisi operasional dari lingkungan ialah kesatuan ruang dengan semua benda dan keadaan makhluk hidup dengan sikap dan perilaku yang berinteraksi dan mempengaruhi kehidupan makhluk hidup itu.

Menurut Kamus Umum Bahasa Indonesia (2002:846) kesadaran lingkungan ialah pengertian yang mendalam pada seseorang atau sekelompok orang yang terwujud dalam pemikiran, sikap dan tingkah laku yang mendukung pengembangan lingkungan.

Menurut Soemarwoto (2001:78) kesadaran lingkungan ialah kesadaran masyarakat dimulai dari pengetahuannya menjaga kelangsungan lingkungan hidup. Pengetahuan yang diterima masyarakat tidak menjelma menjadi kesadaran lingkungan hidup yang menumbuhkan komitmen ramah lingkungan.

Kesadaran masyarakat dalam lingkungan menurut Hirnawan (1998:97) timbul dari persepsi atau informasi tentang berbagai aspek lingkungan yang mendukungnya. Kesadaran timbul akibat proses berpikir orang dalam mengetahui lingkungan di sekitarnya dan persepsi untuk bertindak. Kesadaran itu meningkat sejalan dengan banyaknya informasi yang diserap dalam lingkungan yang terus membinanya, makin berkembang persepsi atau wawasan yang terbina, makin menghayati, meyakini dan mengamalkan dengan baik. 
Dari teori-teori di atas, maka dapat diberikan pengertian operasional seperti berikut ini. Pertama, pengetahuan merupakan bagian dari kesadaran. Pengetahuan tentang hal yang nyata dimaksudkan adalah pengetahuan yang mendalam (menggugah jiwa), tahu sungguh-sungguh, dan tidak salah. Orang yang memiliki pengetahuan lingkungan hidup belum tentu sadar karena sikap/perilakunya yang suka merusak lingkungan seperti menebang pohon sembarangan. Sikap inilah yang tidak mendukung terciptanya kelestarian lingkungan hidup. Kedua, kesadaran adalah bagian dari sikap dan perilaku. Sikap menurut Kamus Umum Bahasa Indonesia (1982:944) adalah melakukan suatu langkah atau tindakan. Pengertian kesadaran yang ada sebagian dari sikap menjadi benar jika sikap yang ditunjukkannya terus bertambah dan menjadi sifat hidupnya.

Contoh yang bisa memperjelas pengertian ini yaitu membersihkan saluran di depan rumah. Jika ada pengetahuan bahwa membersihkan saluran itu penting, maka manusia tersebut menunjukkan bahwa ia sadar lingkungan. Ketiga gaya hidup mempengaruhi kesadaran lingkungan. Gaya hidup menurut Kamus Umum Bahasa Indonesia (1982:302) adalah pola tingkah laku sehari-hari segolongan manusia di dalam masyarakat. Pada saat dalam kesulitan seperti ini segala sesuatu dapat dilakukan tidak pandang yang dilakukan baik atau buruk, sehingga apabila ada tawaran untuk penggundulan hutan, atau kegiatan illegal lainnya pasti dilakukan, gaya hidup yang masa bodoh serta keserakahan manusia untuk mendapatkan keuntungan sebesar-besarnya yang menjadi penyebabnya. Warga yang memiliki gaya hidup masa bodoh tidak akan mengikuti aturan pemerintah dan ajaran agama seperti berjualan di trotoar (pedagang kaki lima) yang menyebabkan penyempitan jalan. Dalam agamapun dikatakan bahwa kebersihan merupakan sebagian dari iman, namun masih banyak warga yang tidak menjaga kebersihan dengan membuang sampah sembarangan. Oleh karena itu dapat diasumsikan bahwa gaya hidup dapat mempengaruhi kesadaran linkungan.

Banjir banyak terjadi di Jakarta karena Jakarta merupakan salah satu dataran rendah. Jakarta adalah satu-satunya kota di Indonesia yang memiliki status setingkat provinsi. Jakarta memiliki luas sekitar 661,52 km² (lautan: 6.977,5 km²), dengan penduduk berjumlah 8.522 .589 jiwa (2010). Khusus penduduk yang terdapat pada wilayah Jakarta Timur berjumlah 2.625.737 jiwa.

Wilayah Jakarta Timur terdiri 95\% daratan dan selebihnya rawa atau persawahan dengan ketinggian rata-rata $50 \mathrm{~m}$ dari permukaan air laut serta dilewati oleh 7 (tujuh) aliran sungai/kali. 
Sungai/kali tersebut antara lain: Kali Cakung, Kali Ciliwung, Kali Malang, Kali Sunter, Kali Cipinang, Kali Buaran, Kali Jati Kramat, Kali Baru. Bila ketujuh aliran sungai meluap, daerah yang dilintasinya adalah daerah potensi banjir. Curah hujan rata-rata $2.000 \mathrm{~mm}$ per tahun sampai dengan maksimum bulan Januari.

Menurut Wahyu (2009:32) banjir merupakan fenomena alam yang terjadi di suatu kawasan yang banyak dialiri oleh aliran sungai. Secara sederhana banjir dapat didefinisikan sebagai hadirnya air di suatu kawasan luas sehingga menutupi permukaan bumi kawasan tersebut.

Menurut Yulaelawati (2008:32) banjir adalah meluapnya aliran sungai akibat air melebihi kapasitas tampungan sungai sehingga meluap dan menggenangi dataran atau daerah yang lebih rendah disekitarnya. Banjir sebenarnya merupakan fenomena kejadian alam yang sering terjadi dan dihadapi hampir diseluruh negara-negara di dunia, termasuk Indonesia. Karena sesuai kodratnya, air akan mengalir dan mencari tempat-tempat yang lebih rendah.

Banjir akan menjadi masalah apabila dataran banjir yang bersangkutan telah dikembangkan/dibudidayakan menjadi permukiman, perkotaan, pertanian, kawasan industry dan sebagainya. Banjir menjadi bermasalah apabila banjir tersebut memberikan dampak kerusakan dan dampak negatif terhadap lingkungan manusia. Seperti kerusakan (jalan, jaringan air bersih, fasilitas umum dan prasarana lainnya), terganggunya kehidupan masyarakat dan aktifitas ekonomi serta menurunnya kualitas lingkungan.

Banyaknya persoalan banjir di Jakarta perlu dikaji secara mendalam. Seluruh faktor penyebab harus diungkap dan jalan pemecahannya perlu dicari agar ditindaklanjuti secara serius.

Adapun faktor penyebab banjir di Kodya Jakarta Timur menurut Satlak PBP Kota Adm. Jakarta Timur (2007:10), yaitu:

a. Dataran rendah

b. Di aliri 7 (tujuh) sungai

C. Hujan local dan Bopunjur (Bogor, Puncak, Cianjur)

d. Penyempitan dan pendangkalan sungai

e. Kepadatan penduduk $(85.700 / \mathrm{km})$

f. Kesadaran warga yang rendah 
g. Penumpukan sampah di darat maupun di sungai

h. Bangunan/gubuk di bantaran

i. Kurangnya Ruang Terbuka Hijau (RTH)

Dari berbagai masalah yang telah disebutkan di atas, masalah yang akan diteliti dibatasi pada masalah mengenai kesadaran lingkungan hanya pada masyarakat Jakarta Timur yang setiap tahunnya menerima bencana banjir besar se-JABODETABEK.

\section{METODA}

Dalam penelitian ini metode yang digunakan adalah metode deskriptif yang bersifat survei. Penelitian ini yang menjadi objek yaitu kesadaran lingkungan masyarakat Jakarta Timur.

Populasi dalam penelitian ini adalah seluruh masyarakat Jakarta Timur yang menurut data Suku Dinas Kependudukan dan Pencatatan Sipil Kota Administrasi (2010) berjumlah 2.625.737 jiwa. Dengan jumlah WNI 2.626.482 jiwa dan WNA 226 jiwa.

Sampel yang digunakan dalam penelitian ini adalah purposive sampel yaitu metode pengambilan sampel yang tidak acak. Dalam hal ini sampel dipilih berdasarkan pertimbangan-pertimbangan tertentu. Sedangkan pertimbangan yang diambil itu berdasarkan tujuan penelitian. Sampel dalam penelitian ini adalah masyarakat Jakarta Timur yang setiap tahunnya menerima bencana banjir yang diambil 160 orang responden (40 Kepala Keluarga) yang terdiri dari 40 responden ayah, 40 responden ibu, 40 responden anak laki-laki dan 40 responden anak perempuan. Responden anak laki-laki dan perempuan dewasa dibatasi pada usia minimum 15 tahun.

Data yang dibutuhkan dalam penelitian ini diperoleh melalui instrumen. Instrumen yang baik dan benar akan mampu menghimpun data secara obyektif, lengkap, dan dapat diolah untuk memecahkan masalah penelitian. Teknik pengumpulan data yang digunakan berupa kuesioner atau angket. Penyusunan instrumen pada penelitian ini sesuai indikator-indikator dari kesadaran lingkungan masyarakat DKI Jakarta yaitu pengetahuan, sikap/perilaku dan gaya hidup.

Sebelum angket digunakan dalam penelitian, terlebih dahulu angket diuji-cobakan terhadap sampel. Adapun sampel uji coba yang diambil sebanyak 30 orang pada wilayah di Jakarta Timur. Dalam uji-coba, responden diberi kesempatan untuk memberikan saran-saran perbaikan bagi 
kuesioner yang diuji-cobakan itu. Situasi sewaktu uji-coba dilaksanakan harus sama dengan situasi kapan penelitian yang sesungguhnya akan dilaksanakan.

Setelah itu menghitung validitas untuk menunjukan tingkat-tingkat kevalidan atau kesahihan suatu instrumen. Suatu instrumen yang valid atau sahih mempunyai validitas tinggi. Sebaliknya instrumen yang kurang valid berarti memiliki validitas rendah (Arikunto, 2002). Uji validitas disusun berdasarkan langkah-langkah dalam penyusunan instrumen. Aspek-aspek tersebut ditinjau dan dikembangkan dari indikator, yaitu kegiatan-kegiatan yang mempengaruhi kesadaran lingkungan masyarakat Jakarta Timur. Serta hitung koefisien reliabilitas instrument yang digunakan untuk melihat konsistensi jawaban yang diberikan oleh responden.

Teknik analisis data yang digunakan adalah analisis kualitatif. Teknik analisis data yang dimaksud dalam penelitian ini adalah analisis terhadap data, yang diperoleh dari angket atau kuesioner. Setelah dianalisis kemudian dilihat sehingga akan diperoleh suatu kebenaran dalam hasil penelitian.

Setelah pengolahan data diketahui, maka hasil penelitiannya bahwa orang tua yang memiliki kesadaran lingkungan di DKI Jakarta hanya berkisar $51,13 \%$. Nilai kesadaran lingkungan yang dimiliki orang tua berdasarkan hasil kuesioner masih kurang baik yaitu sebesar $55,63 \%$. Padahal jika dilihat dari pernyataan orang tua yang memiliki prosentase tertinggi 87,5\% yaitu "Tidak setuju menggunakan jamban umum" menunjukkan bahwa masyarakat DKI Jakarta sudah jarang menggunakan jamban umum yang artinya masyarakat peduli dengan kebersihan lingkungan. Namun hasil prosentase dari pernyataan tersebut tidak cukup mewakili kesadaran lingkungan yang dimiliki orang tua.

Kesadaran yang dimiliki orang tua sudah didukung oleh informasi atau pengetahuan yang dimiliki tentang berbagai aspek lingkungan. Pengetahuan yang dimiliki orang tua tidak diimbangi dengan sikap/perilaku mereka terhadap lingkungan, inipun juga terlihat dalam hal gaya hidup masih belum sepenuhnya untuk bisa membiasakan diri membuang sampah pada tempatnya. Hal yang sebagian kecil inilah yang dapat merusak kebersihan lingkungan serta tersumbatnya saluran drainase yang akan menyebabkan banjir.

Anak yang memiliki kesadaran lingkungan di DKI Jakarta hanya berkisar 50,57\%. Nilai kesadaran lingkungan anak berdasarkan hasil kuesioner masih kurang yaitu sebesar 49,86\%. Padahal responden anak sudah banyak yang mengerti dalam mengantisipasi banjir seperti yang 
terlihat pada prosentase tertinggi 95\% responden anak laki-laki menyatakan "Setuju untuk menyarankan orang tua meninggikan rumah agar banjir tidak masuk ke dalam rumah". Sedangkan pada responden anak perempuan 87,5\% pada pernyataan "Setuju untuk menyarankan orang tua membuat rumah bertingkat". Hal ini menununjukkan bahwa anak hanya memiliki pemikiran jangka pendek dalam mengantisipasi banjir.

Pengetahuan yang dimiliki tentang berbagai aspek lingkungan belum tentu mendukung bertambahnya kesadaran lingkungan meskipun telah dibina oleh orang tua. Dalam hal gaya hidup sudah sebagian besar terlihat bahwa orang tua selalu mengajarkan anak untuk bisa membiasakan diri membuang sampah pada tempatnya. Namun, pengetahuan yang dimiliki anak belum diimbangi dengan sikap/perilaku mereka terhadap lingkungan.

Kesadaran lingkungan akan timbul apabila seorang individu mengetahui sesuatu atau tahu bersikap yang seharusnya, yang didukung oleh persepsi atau informasi tentang berbagai aspek lingkungan. Namun pada kenyataannya dilihat dari data survei bahwa kesadaran lingkungan masyarakat DKI Jakarta (khususnya Jakarta Timur) masih terlihat belum sepenuhnya memiliki yaitu hanya sebesar $52,74 \%$, masyarakat yang memiliki kesadaran lingkungan itu pun hanya berkisar 50,85\%. Pengetahuan atau informasi yang mereka miliki serta pembinaan yang mereka dapatkan dari aparat setempat belum sepenuhnya diwujudkan melalui sikap/perilaku mereka.

Dampak negatif pembangunan yang tidak terkendali berupa ketidakseimbangan lingkungan seringkali ditandai oleh erosi yang berlebihan, penurunan lahan, banjir, longsor, kekeringan. Sementara itu, di kota-kota besar seperti Jakarta buangan limbah industri maupun limbah domestik berupa sampah padat dan cair masih belum terkendali akibat perilaku sebagian masyarakat yang tidak peduli dengan lingkungan. Walaupun hanya sebagian kecil warga yang tidak peduli lingkungan, namun hal inilah yang bisa berdampak besar bagi masyarakat luas. Ketidakpedulian mereka menandakan tidak adanya kesadaran lingkungan. Sungai-sungai dijadikan tempat buangan limbah, yang tidak hanya dilakukan oleh beberapa masyarakat pada umumnya, tetapi justru oleh para pengusaha yang tidak bertanggung jawab.

Pengawasan pembangunan gubuk liar di daerah aliran sungai (DAS) oleh aparat pemerintah masih sangat longgar, sehingga banyak warga yang mendirikan bangunan liar disekitarnya. 
Bangunan liar seperti inilah yang menyebabkan penyempitan aliran sungai sehingga ketika hujan berlangsung sungai/kali tersebut akan meluap dan menyebabkan banjir. Perlu adanya peran serta pemerintah atau aparat setempat untuk terus membina warga dalam menumbuhkan sikap kesadaran lingkungan sehingga masyarakat bisa menjaga lingkungan guna mengurangi bencana banjir.

Berdasarkan hasil penelitian yaitu tentang Kesadaran Lingkungan Masyarakat Jakarta Timur dalam Mengantisipasi Bencana Banjir Besar se-JABODETABEK ditinjau dari karakteristiknya maka dapat diambil kesimpulan sebagai berikut:

1. Kesadaran lingkungan yang dimiliki oleh masyarakat DKI Jakarta hanya sebesar $52,74 \%$. Adapun jumlah warga yang memiliki kesadaran lingkungan sebanyak 50,85\%. Ini menunjukkan bahwa kesadaran lingkungan masyarakat DKI Jakarta masih kurang.

2. Warga yang memiliki pengetahuan yang baik tentang sadar lingkungan sebanyak $35,415 \%$. Namun terkadang beberapa warga tidak mengimbangi pengetahuan yang mereka miliki dengan sikap/perilakunya.

3. Warga masih terlihat ragu-ragu untuk mengolah sampah di lingkungan sendiri untuk dijadikan sesuatu yang bermanfaat. Ini terlihat dari warga yang memiliki sikap/perilaku kesadaran lingkungan hanya 44,64\%, namun sikap/perilaku mereka dalam mengantisipasi bencana banjir sudah baik seperti meninggikan rumah, membuat rumah bertingkat dan menyiapkan papan tanggul ketika hujan tiba. Terlihat bahwa masyarakat DKI Jakarta (khususnya Jakarta Timur) hanya memikirkan antisipasi banjir dalam waktu jangka pendek tanpa memikirkan generasi yang akan datang.

4. Gaya hidup untuk membiasakan membuang sampah pada tempatnya sebanyak $72,5 \%$ warga sudah baik. Namun sebagian kecil dari warga masih ada yang membuang sampah di saluran sehingga membuat saluran tersumbat. Hal sebagian kecil inilah yang bisa menimbulkan banjir yang akan berdampak besar bagi banyak orang.

5. Faktor ekonomi yang kurang mendukung serta lokasi yang strategis membuat warga sulit untuk pindah dari lingkungan rawan banjir dan bagi anak-anak mereka sudah merasa nyaman tinggal di lingkungan rawan banjir.

6. Beberapa warga memiliki pengetahuan yang baik mengenai kesadaran lingkungan, namun tidak diaplikasikan secara nyata dalam sikap/perilaku serta gaya hidup yang mencintai lingkungan. Sebagian besar masyarakat hanya memiliki kesadaran lingkungan 
dalam waktu jangka pendek guna mengantisipasi banjir tanpa memikirkan antisipasi banjir dalam waktu jangka panjang sehingga mereka terlihat kurang peduli terhadap generasi penerus yang akan datang.

Dalam menimbulkan kesadaran lingkungan masyarakat Jakarta Timur yang harus dilkukan pihak Pemerintah, pengelola (RT/RW) adalah:

a. Perlu dukungan dan motivasi dari pihak terkait seperti pemerintah dalam bentuk penyuluhan dan pemberian modal untuk membina warganya mengolah sampah menjadi sesuatu yang bermanfaat sehingga dapat meyakinkan warga dengan terciptanya lapangan pekerjaan serta sampahpun dapat diminimalisirkan.

b. Pemerintah ataupun pengelola membuat suatu penyuluhan tentang antisipasi banjir dalam waktu jangka pendek dan jangka panjang sehingga dapat minimbulkan kesadaran lingkungan bagi warganya.

c. Pemerintah memasang papan larangan "Dilarang keras membuang sampah di saluran" di sekitar saluran drainase serta memberikan sangsi kepada warga yang terlihat membuang sampah di saluran.

d. Diharapkan pemerintah membuat pagar tinggi di sepanjang kali sehingga kemungkinan warga untuk menggunakan kali, membuang sampah ke kali itu akan kecil.

e. Diharapkan pemerintah setempat megadakan perlombaan bersih lingkungan dengan memberi reward kepada warga yang memiliki lingkungan tempat tinggal yang paling bersih. Program ini memungkinkan warga untuk termotivasi terus menerus dalam menjaga kebersihan lingkungan sehingga banjir dapat diantisipasi, kesadaran lingkungan yang tinggi dapat tercipta dan warga tidak perlu lagi mencari tempat tinggal yang lain.

f. Pemerintah menggalakkan penggusuran bagi warga yang tinggal di daerah bantaran kali serta memberikan alternatif pilihan dengan memberikan uang atau tempat tinggal yang nyaman sebagai penggantinya.

g. Diharapkan program yang telah berjalan tetap berjalan terus menerus dan berkesinambungan agar terciptanya kesadaran lingkungan yang tinggi bagi warga Jakarta Timur.

Kewajiban pihak warga yang terkena banjir di wilayah Jakarta Timur adalah: 
a. Kerjasama antar warga untuk saling merawat dan menjaga lingkungan.

b. Selalu mengingat Tuhan karena kebersihan itu sebagian dari iman. Dengan beriman kepada Tuhan maka akan tercipta kesadaran lingkungan yang tinggi dan selalu menjaga lingkungan agar tetap bersih.

c. Pengetahuan yang dimiliki oleh warga tentang sadar lingkungan harus diimbangi dalam prakteknya.

d. Mematuhi himbauan dari pihak pengelola (RT/RW) dalam melakukan kerja bakti yang diadakan setiap bulannya.

e. Dihimbau agar warga berperan aktif dalam pendaur ulangan sampah sehingga dapat penghasilan tambahan bagi warga.

f. Menyediakan tempat sampah yang berbeda antara sampah organik dan anorganik. 